BROOKHAVEN NATIONAL LABORATORY

AADD 73-17 Associated Universities, Inc. Upton, New York

ACCELERATOR DEPARTMENT

Informal Report

\title{
ECCENTRIC RF DEFLECTING STRUCTURE
}

\author{
J.R. Aggus, S. Giordano and H.J. Halama
}

December 13,1973

\section{$N O T$ I C E}

$i$

This report was prepared as an account of work sponsored by the United States Government. Neither the United States nor the United States Atomic Energy Commission, nor any of their employees, nor any of their contractors, subcontractors, or their employees, makes any warranty, express or implied, or assumes any legal liability or responsibility for the accuracy, completeness or usefulness of any information, apparatus, product or process disclosed, or represents that its use would not infringe privately owned rights. 


\section{Abstract}

For superconducting RF separators, assembled by electron beam welding techniques, two types of mode stabilizers are discussed: the elliptical structure, and a new design called the "eccentric structure". For an operating $\pi / 2$ or $\pi$ mode in the lower pass band, it is shown that the various parameters of the eccentric structure can be adjusted to provide the required frequency spacing between the operating mode and the upper dispersion curve.

Due to machining and fabrication tolerances in a typical iris loaded deflecting cavity, it is possible for the transverse deflecting fields to become elliptically polarized, resulting in a rotation of the fields along the length of the structure. For room temperature structures, the machining of flats or the use of rods placed axially down the structure are used to stabilize the mode. Since room temperature structures, made of copper, are assembled by brazing, the above types of mode stabilizers can be used, but for niobium superconducting cavities, which must be assembled by tectron beam welding, these stabilizers are not compatible with the aval lable electron beam welding techniques.

There are two basic requirements a joint must have to be electron beam welded: first the joint must be optically visible to the electron beam, and secondly, the joint must have a uniform thickness along its length.

Mode stabilizers which meet the above requirements have been suggested in Ref. 1. By using elliptically shaped cavity irises (Fig. 1), it is possible to maintain a constant joint thickness $T$, but the machining is both time consuming and costly.

A new type of mode stabilizer, which one shall henceforth refer to as the "eccentric structure", was suggested by the authors in Refs. 2 and 3, and is shown in Fig. 2. The fabrication is accomplished by first final machining the bore hole and sloping side of the iris truly concentric and symmetrical to the cavity center line up to a radius $R_{0}$. The eccentric portion is then machined by moving the cavity off center in the lathe by $d / 2$. 
The tool is then moved into the work axially at a radius $R_{0}$ to the required depth. The tool is then moved radially toward the center of the work unt 1 It has cleared the angled face. The eccentric portion, therefore, is octually a small portion of a cylinder. The process is then repeated on the other half of the cavity for aymetry. The weld joint diametere $2 \mathrm{R}_{0}+\mathrm{d}$ and $2 \mathrm{R}_{0}+2 \mathrm{~T}+\mathrm{d}$ then machined concentric to the axis of the cavity. This method of fabrication enables the electron beam weld joint to remin truly chrcular and of constant thickness $T$.

It la now necessary to conaider the eloctrical cheracteristica of the eccentric atructure as a function of the variables $d$ and $W$ in Fig. 2 . For the deflecting mode, all mode ttabilizers have the effect of splitting tha disperaion curve Into two separate dispersion curves, where the corresponding modes in each of the dfspersion curves are in space quadracure co cach other. Once an oparating mode has been eelected (in one of the dispersion curvea), It it necesary that a suffictently large frequency differeace exiat between It (the operating wode) and any mode in the other dispersion curve. It will now be hown how this frequency difference is related to the garraters d and $N$.

Kasuremente were mude on 44 cell model at $2.8 \mathrm{Gtz}$, Show in ffs. 3 are the typical dieperation curves obtained. The $n / 2$ mode in the lower pass band, at $\omega_{0}$, has been eelected as the operating mode, and che frequency saparation between it and the upper pase band is w. (Thare are reatonf for celecting this mode, but they will not be discussed here.) The reaults of these mearurements are shown in the table. It should bs polnted out thet there was no degradation of the $Q$ in any of che messurtis structures.

\begin{tabular}{|l|l|l|}
\hline$d$ & $\begin{array}{l}\omega \\
(m)\end{array}$ & $\frac{0 \mathrm{p}}{0}$ \\
\hline 0.61 & 0 & 0.0055 \\
0.61 & 1.0 & 0.0035 \\
0.61 & 2.0 & 0.00176 \\
0.76 & 2.0 & 0.006 \\
\hline
\end{tabular}

Table 
For a practical operating $\pi / 2$ mode structure, a minimum $\frac{\Delta_{w}}{\omega_{0}}$ of 0.003 would be desirable. To accommodate the electron beam welding, the width $w$ should be at least $2 \mathrm{~mm}$. Fron the table, we see that $d=0.076 \mathrm{~mm}$ and $T=2.0 \mathrm{wm}$ meets our requirements. It should be pointed out that there is essentially no field in the gap $T$ for the operating $\pi / 2$ mode.

Consideration has also been given to the use of the lower $\pi$ mode as the operating mode. Clearly, the requited frequency spacing between it and the upper pass band can be readily achieved.

\section{References}

1. H. Bauer, Theals, Report Kernforechungszentrum Karlaruhe, KFK 1550 (1971).

2. J. Aggus, H. Batter, S. Clordano, H. Hahn and H.J. Halama, BNL 18292, ANDD $73-14$ (1973)

3. J. Aggus, H. Baver, S. Giordano, H. Hahn and H.J. Halama, IEEE Trans. Nuch. Sci. WS-20 No. 3, (1973). 


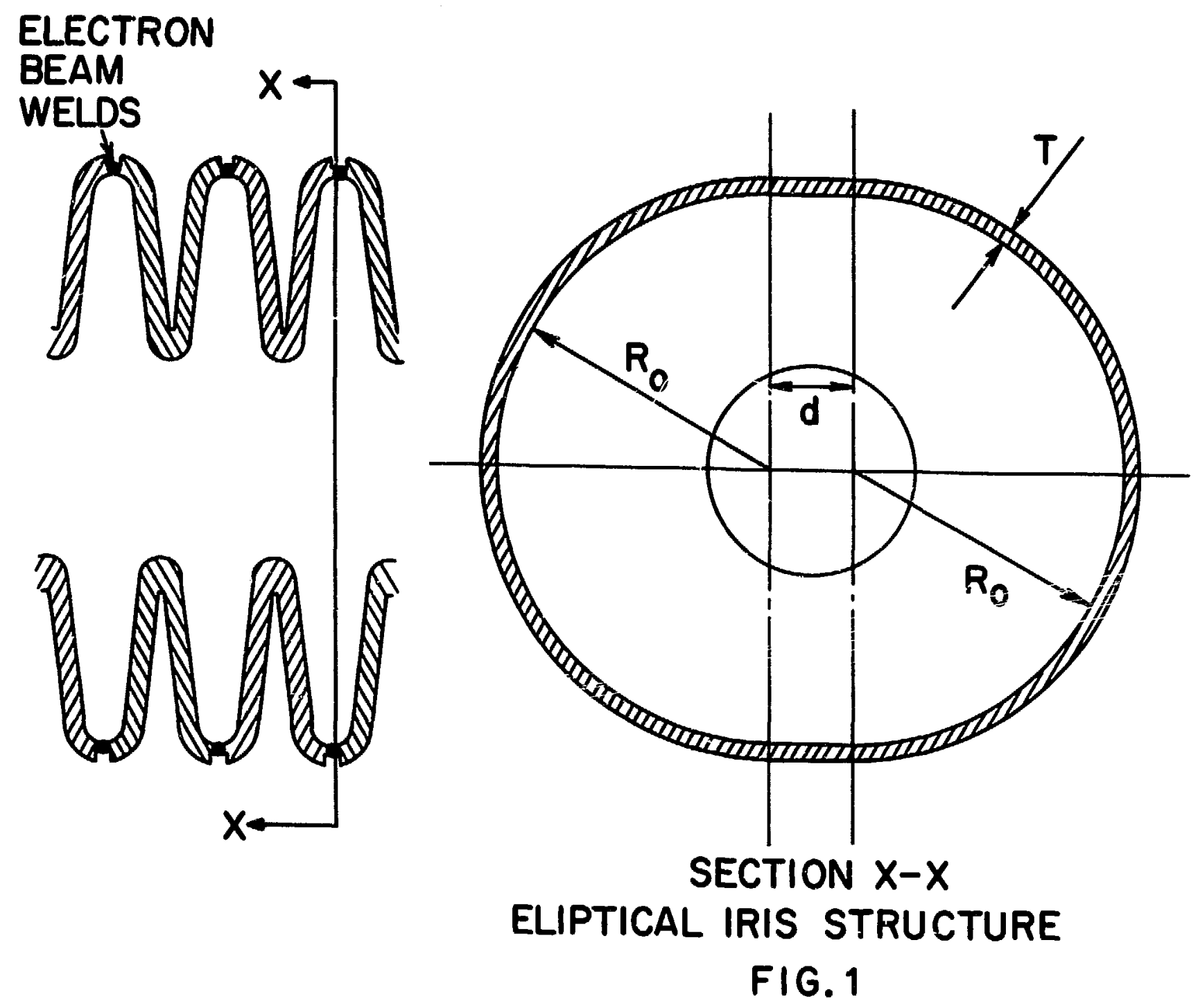




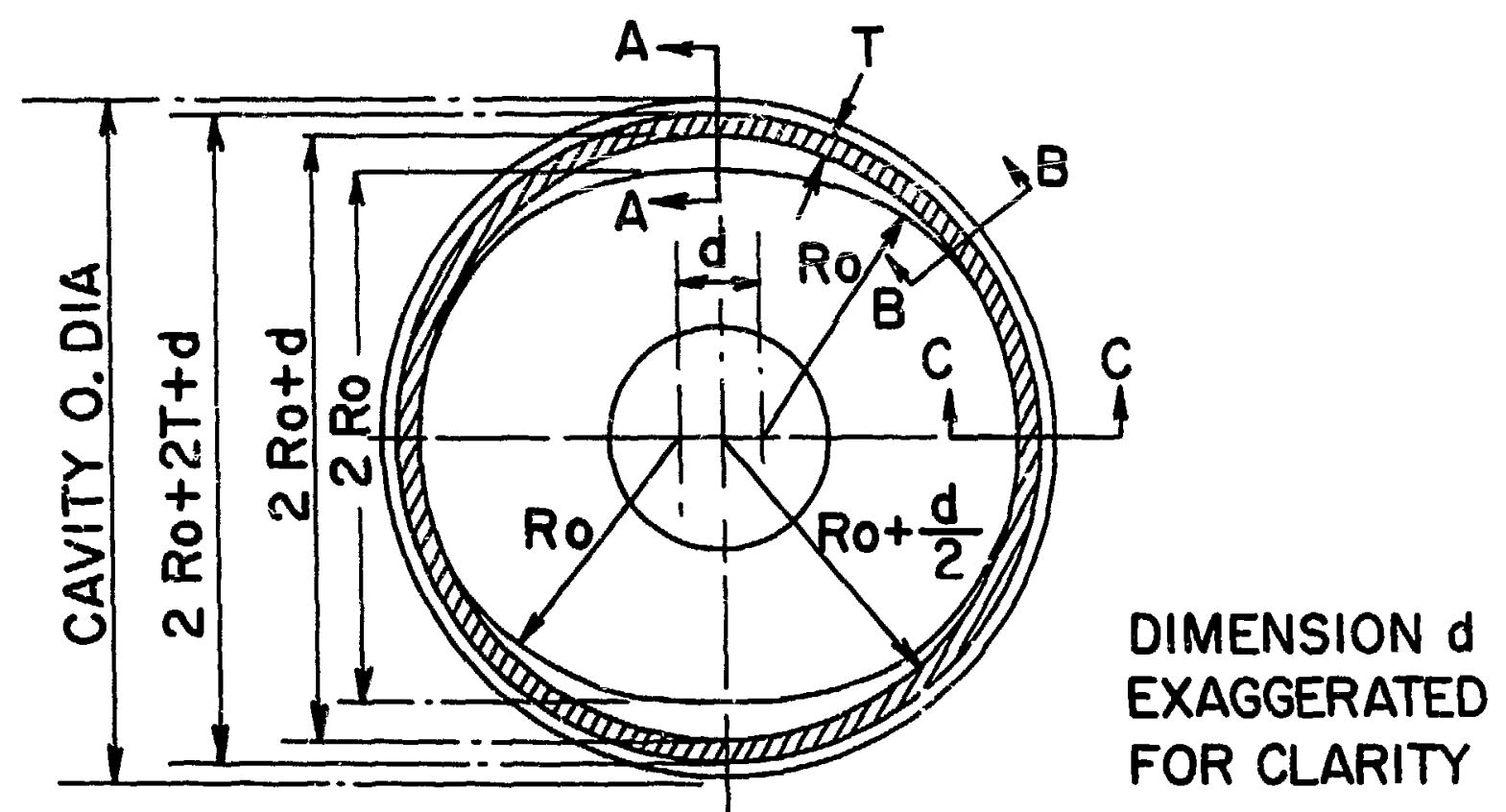

ELECTRON BEAM WELD

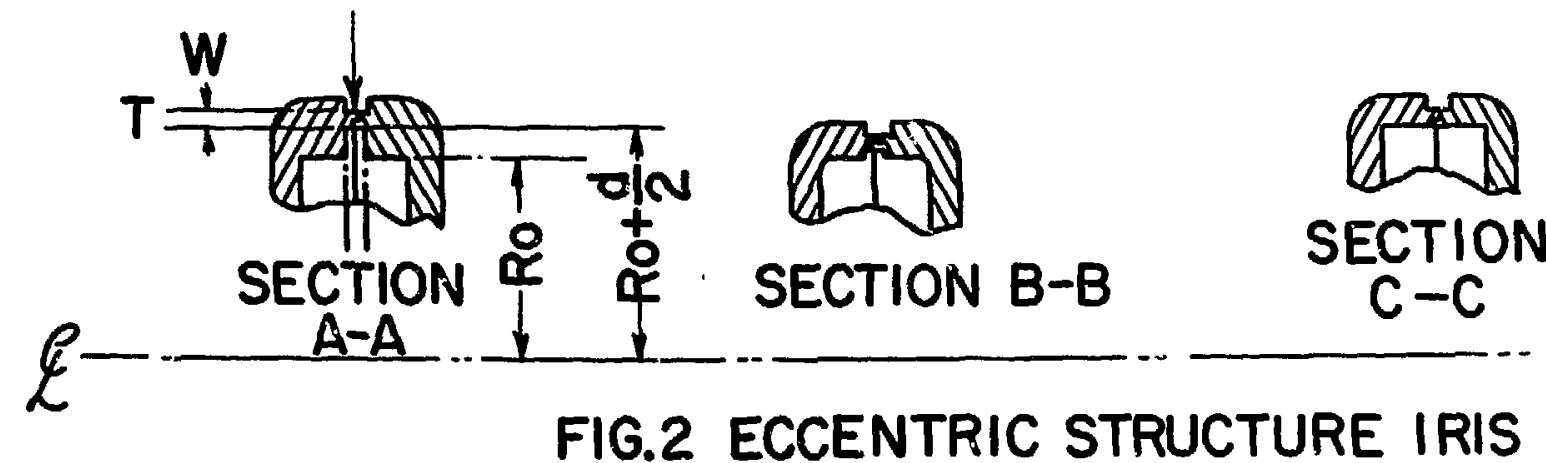

FIG.2 ECCENTRIC STRUCTURE IRIS 


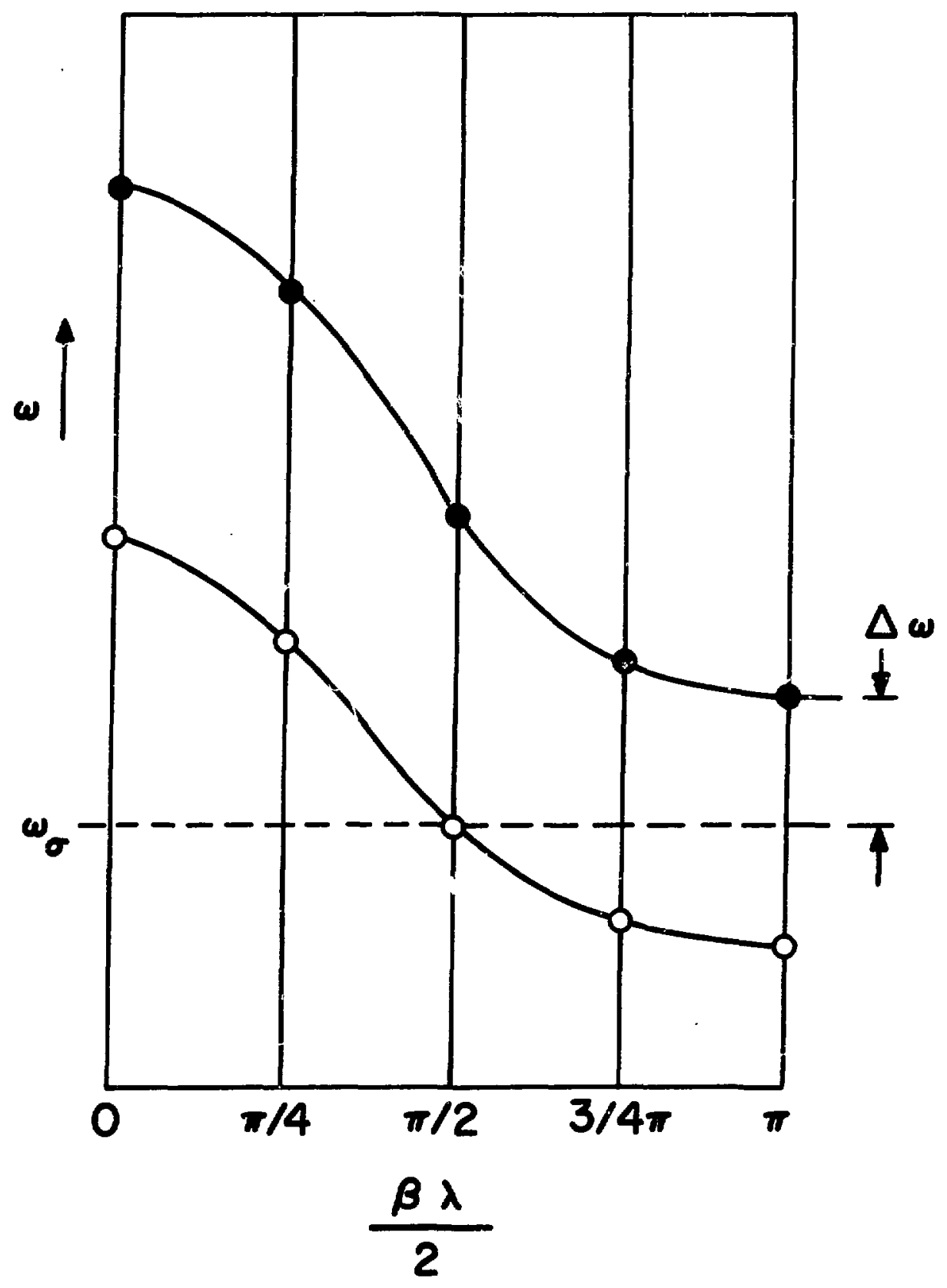

FIG.3 DISPERSION CURVE 